\title{
Synthesis and optimization ring opening of monoepoxide linoleic acid using $p$-toluenesulfonic acid
}

\author{
Jumat Salimon*, Bashar Mudhaffar Abdullah, Rahimi M Yusop, Nadia Salih and Emad Yousif
}

\begin{abstract}
Biolubricant base oils, 9,12-hydroxy-10,13-oleioxy-12-octadecanoic acid (HYOOA) was synthesized based on the esterification reaction of Monoepoxide linoleic acid 9(12)-10(13)-monoepoxy 12(9)-octadecanoic acid (MEOA) with oleic acid (OA) and catalyzed by $p$-Toluenesulfonic acid. The optimum conditions for the experiment using D-optimal design to obtain high yield\% of 84.61 , conversion\% of 83.54 and lowest OOC\% of 0.05 were predicted at OA/MEOA ratio of 0.2:1 ( $\mathrm{mol} / \mathrm{mol})$, PTSA/MEOA ratio of $0.4: 1(\mathrm{~mol} / \mathrm{mol})$, reaction temperature at $110^{\circ} \mathrm{C}$, and reaction time at $4.5 \mathrm{~h}$. The FTIR peaks of HYOOA indicate the disappearance of the absorption band at $820 \mathrm{~cm}^{-1}$, which belongs to the oxirane ring. ${ }^{13} \mathrm{C}$ and ${ }^{1} \mathrm{H}$ NMR spectra analyses confirmed the result of HYOOA with appearance carbon-ester $(C=0)$ chemical shift at $174.1 \mathrm{ppm}$ and at $4.06 \mathrm{ppm}$ for ${ }^{13} \mathrm{C}$ and ${ }^{1} \mathrm{H}$ NMR respectively.
\end{abstract}

\section{Introduction}

Plant oil based products have become more cost competitive with their petroleum derived counterparts as crude petroleum oil prices have increased dramatically in recent years due to a number of geopolitical factors (Moser et al. 2007). Fatty acid esters are natural oleochemicals and can be used for many industrial purposes. Oleic acid (OA) is one of the most important fatty acid. OA is generally considered being the predominant fatty acid in nature. Esters are one of the most important derivatives of OA. OA, esters of OA and various derivatives of OA can be used as a lubricating oil (Özgülsün \& Karasmanoğlu 1999). A variety of chemical modifications of epoxidized plant oils and fatty acids are possible through epoxy moiety, and one of the most commonly used is the ring opening reaction. Due to the high reactivity of the oxirane ring, the epoxidation of the double bonds opens up a wide range of feasible reactions that can be carried out under moderate reaction conditions (Lozada et al. 2009).

Many studies have been carried out for oxirane ring opening using different alcohols, catalysts and carboxylic acids. The oxirane ring opening of epoxidized plant oils by hydrolysis and hydrogen peroxide in two-phase

\footnotetext{
*Correspondence: jumat@ukm.my

School of Chemical Sciences \& Food Technology, Faculty of Science and Technology, Universiti Kebangsaan Malaysia, 43600 Bangi, Selangor, Malaysia
}

(polar-organic) systems, when a homogeneous acid catalyst is used was done by Campanella \& Baltanás (2005). Acid hydrolysis of epoxidized plant oils is a very slow reaction that proceeds at the liquid-liquid inter phase. The results showed that the transport was controlled, as the influence of temperature was found to be almost negligible. While the degradation of epoxidized plant oils with hydrogen peroxide using an ion exchange resin (Amberlite IR-120) was also done by Campanella \& Baltanás (2005). The result showed that the ring opening increased either by adding a higher amount of catalyst to the system or by decreasing the particle size of the catalyst since, in both cases, the external area of the catalyst became larger. The ring-opening reaction of epoxidized plant oil using Amberlyst 15 (Dry) catalysis was carried out by Lathi \& Mattiasson (2007).

$p$-Toluenesulfonic acid (PTSA) was preferred to use in the reactions due by the maximum yield of epoxy ring opening and no evidence of any side reaction occurs during the reaction. A screening study was conducted to identify a catalyst that promotes epoxy ring opening of full epoxidized soybean oil avoiding side reactions at low concentration and temperature. Six catalysts different catalyst: formic acid, phosphoric acid, POLYCATVR 5, PTSA, POLYCATVR SA-1, and DABCOVR BL17 were evaluated in terms of acid number, oxirane oxygen 
content, and color analyses. PTSA shows a particular behavior that promotes the reaction resulting in a maximum oxirane oxygen content reduction; low acid number and color index compare to the others catalyst (Lozada et al. 2009).

Amongst these classes of products, hydroxyl esters find application as lubricants, polyurethane foams or casting resins. The physicochemical properties of lubricants derived from hydroxyl esters can be modified or altered using different carboxylic acids. The nature and size of the carbon chain, e.g., influence the product's viscosity (Schuster et al. 2008).

In this study, the oxirane ring opening reaction of monoepoxide linoleic acid (MEOA) by the nucleophilic addition of $\mathrm{OA}$ in the presence of a homogeneous acid catalyst, such as $p$-toluenesulfonic acid (PTSA), to prepare 9,12-hydroxy-10,13-oleioxy-12-octadecanoic acid (HYOOA) is reported. The effects of different ratios of OA/MEOA, different ratios of PTSA/MEOA, different reaction temperatures, and different reaction times are analyzed by using D-optimal design. The experimental conditions and catalyst used were different from those previously used, leading to better selectivity towards the hydroxyl ester under mild working conditions.

\section{Results and discussion}

\section{Reaction of synthesis of monoester}

Many nucleophilic reagents are known to add to an oxirane ring, resulting in ring opening (Salimon et al. 2012a). These ring opening reactions could result in<smiles>CCCCC/C=C/CC1OC1CCCCCCCC(=O)O</smiles>

(1a)

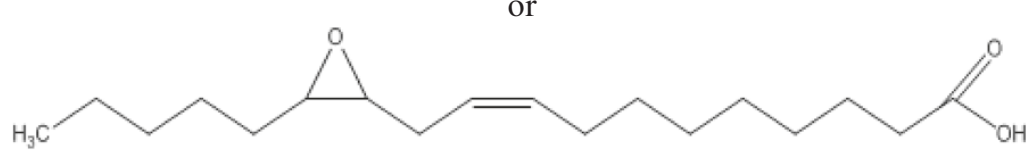

(1b)

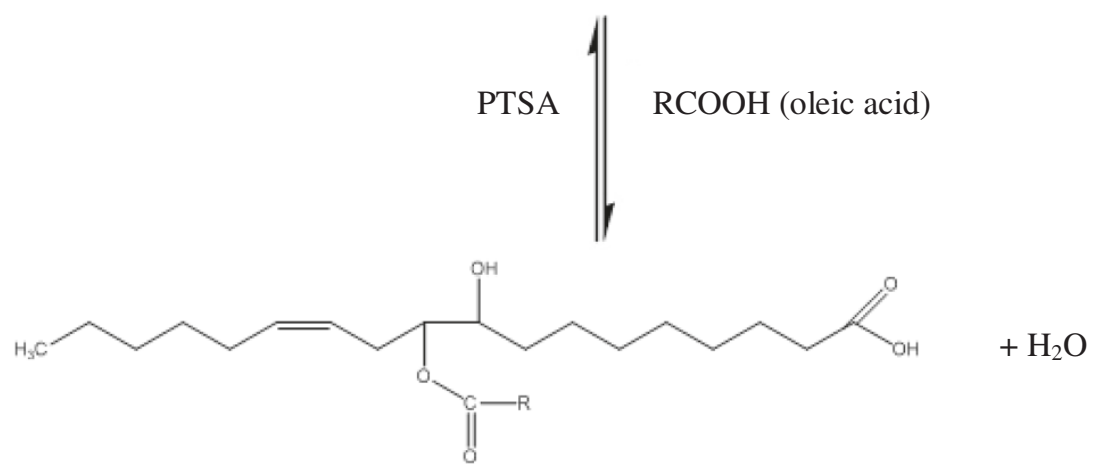

(2a)

or

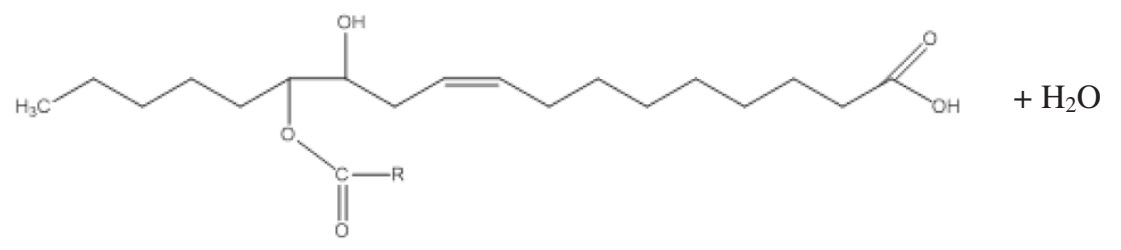

(2b)

Figure 1 Oxirane ring opening reaction to form HYOOA. Notes: 9-10-monoepoxy 12-octadecanoic acid (1a); 12-13-monoepoxy 9-octadecanoic acid (1b); 9-hydroxy-10-oleioxy-12-octadecanoic acid (2a); 12-hydroxy-13-oleioxy-9-octadecanoic acid (2b); $R=0$ leic acid. 
branching at the oxirane ring opening (earlier sites of unsaturation in LA). The appropriate branching groups would interfere with the formation of macrocrystalline structures during low-temperature applications and would provide enhanced fluidity to plant oils. The ester branching groups produced from oxirane ring opening based esterification reaction are effective for attaining the desired molecular spacing. A chain length ester (saturated and unsaturated) has been observed to deliver the most desired physicochemical properties for some oils (Wu et al. 2008). These modified plant oils with chain branching are reported to have superior performance of the physicochemical properties and are

Table 1 D-optimal design arrangement and responses for HYOOA

\begin{tabular}{|c|c|c|c|c|c|c|c|}
\hline \multirow{3}{*}{$\begin{array}{l}\text { Run } \\
\text { No. }\end{array}$} & \multicolumn{4}{|c|}{$\begin{array}{l}\text { Coded independent } \\
\text { variable levels }\end{array}$} & \multicolumn{3}{|c|}{ Responses } \\
\hline & \multicolumn{2}{|c|}{$\begin{array}{l}\mathrm{OA}^{\mathrm{a}} / \mathrm{MEOA}^{\mathrm{b}} \\
\mathrm{PTSA}^{\mathrm{C}} / \mathrm{MEOA}\end{array}$} & \multirow{2}{*}{$\begin{array}{l}\text { Temp. } \\
\left({ }^{\circ} \mathrm{C}, \mathrm{X}_{3}\right)\end{array}$} & \multirow{2}{*}{$\begin{array}{l}\text { Time } \\
\left(h, X_{4}\right)\end{array}$} & \multirow{2}{*}{$\begin{array}{l}\text { OOC }^{d} \\
\left(\%, Y_{1}\right)\end{array}$} & \multirow{2}{*}{$\begin{array}{c}\text { Yield } \\
\left(\%, Y_{2}\right)\end{array}$} & \multirow{2}{*}{$\begin{array}{c}\text { IV } \\
\left(\mathrm{mg} / \mathrm{g}, \mathrm{Y}_{3}\right)\end{array}$} \\
\hline & $\begin{array}{c}(\mathrm{mol} / \\
\left.\mathrm{mol}, \mathrm{X}_{1}\right)\end{array}$ & $\begin{array}{c}(\mathrm{mol} / \\
\left.\mathrm{mol}, \mathrm{X}_{2}\right)\end{array}$ & & & & & \\
\hline Run & \multicolumn{4}{|c|}{$\begin{array}{c}\text { Coded independent variable } \\
\text { levels }\end{array}$} & \multicolumn{3}{|c|}{ Responses } \\
\hline 1 & 0.20 & 0.90 & 90 & 4.50 & 2.60 & 70.5 & 101.4 \\
\hline 2 & 0.20 & 0.40 & 90 & 3.00 & 0.90 & 82.1 & 114.3 \\
\hline 3 & 0.40 & 0.65 & 90 & 4.50 & 3.80 & 61.1 & 84.2 \\
\hline 4 & 0.40 & 0.65 & 100 & 6.00 & 3.20 & 56.4 & 91.9 \\
\hline 5 & 0.40 & 0.40 & 100 & 4.50 & 3.40 & 84.5 & 90.3 \\
\hline 6 & 0.30 & 0.78 & 100 & 3.75 & 3.10 & 70.4 & 94.1 \\
\hline 7 & 0.60 & 0.40 & 110 & 6.00 & 2.70 & 58.3 & 100.2 \\
\hline 8 & 0.60 & 0.40 & 110 & 3.00 & 2.40 & 55.5 & 109.7 \\
\hline 9 & 0.60 & 0.90 & 90 & 6.00 & 2.10 & 27.8 & 110.8 \\
\hline 10 & 0.60 & 0.90 & 90 & 3.00 & 1.80 & 35.7 & 112.3 \\
\hline 11 & 0.20 & 0.40 & 100 & 6.00 & 1.50 & 81.5 & 112.5 \\
\hline 12 & 0.60 & 0.90 & 90 & 3.00 & 2.90 & 55.6 & 99.8 \\
\hline 13 & 0.20 & 0.90 & 110 & 6.00 & 3.05 & 70.9 & 88.5 \\
\hline 14 & 0.60 & 0.40 & 90 & 4.50 & 3.50 & 65.9 & 88.9 \\
\hline 15 & 0.60 & 0.65 & 100 & 4.50 & 0.60 & 74.3 & 122.2 \\
\hline 16 & 0.60 & 0.90 & 90 & 6.00 & 0.80 & 53.7 & 120.4 \\
\hline 17 & 0.60 & 0.90 & 110 & 4.50 & 0.40 & 50.8 & 123.9 \\
\hline 18 & 0.20 & 0.40 & 90 & 3.00 & 0.30 & 80.1 & 125.2 \\
\hline 19 & 0.40 & 0.40 & 90 & 6.00 & 2.95 & 65.1 & 94.1 \\
\hline 20 & 0.60 & 0.40 & 110 & 3.00 & 1.40 & 58.4 & 114.1 \\
\hline 21 & 0.20 & 0.90 & 110 & 3.00 & 0.20 & 79.5 & 127.4 \\
\hline 22 & 0.40 & 0.65 & 110 & 4.50 & 0.90 & 80.1 & 118.7 \\
\hline 23 & 0.60 & 0.40 & 110 & 6.00 & 0.70 & 40.8 & 121.1 \\
\hline 24 & 0.20 & 0.40 & 110 & 4.50 & 0.05 & 84.6 & 134.8 \\
\hline 25 & 0.20 & 0.65 & 90 & 6.00 & 0.60 & 82.4 & 122.5 \\
\hline
\end{tabular}

Notes: oleic acid (a); 9(12)-10(13)-monoepoxy 12(9)-octadecanoic acid (b); p-toluene sulfonic acid (c); oxirane oxygen content (d). promising as biolubricants (Hwang \& Erhan 2001). This work reports the oxirane ring opening reaction of monoepoxide linoleic acid (MEOA) by the nucleophilic addition of oleic acid (OA) in the presence of homogeneous acid catalysts, such as $p$-toluene sulfonic acid (PTSA), to prepare 9,12-hydroxy-10,13-oleioxy-12-octadecanoic acid (HYOOA) (Figure 1) with yield\% of 80.49.

\section{Effect of process parameters and statistical analysis}

Optimization study of the oxirane ring-opening-based esterification reaction using D-optimal design took place in the presence of OA with using PTSA as a catalyst. The design is used to obtain 25 design points within the whole range of four factors for experiments. The designs and the response OOC\% $(Y)$ are given in Table 1 with measuring the yield\% and IV $\mathrm{mg} / \mathrm{g}$. To see the impact on the oxirane ring opening by $\mathrm{OA}$ reaction, different ratios of OA/MEOA $\left(\mathrm{mol} / \mathrm{mol}, X_{1}\right)$, different ratios of PTSA/MEOA ( $\mathrm{mol} / \mathrm{mol}, X_{2}$ ), different reaction temperature $\left({ }^{\circ} \mathrm{C}, X_{3}\right)$, and different reaction time $\left(\mathrm{h}, X_{4}\right)$ were evaluated.

Table 1 illustrates the OOC\%, yield\% and IV $\mathrm{mg} / \mathrm{g}$ effect related to the OA/MEOA ratio, PTSA/MEOA ratio, reaction temperature, and reaction time. As expected, at high temperature, $110^{\circ} \mathrm{C}$, the $\mathrm{OOC} \%$ shows a

Table 2 Regression coefficients of the predicted quadratic polynomial model for the response variables of the OOC\% of HYOOA

\begin{tabular}{|c|c|c|c|c|}
\hline Variables & $\begin{array}{c}\text { Coefficients }(ß), \\
\text { OOC\% }\left(Y_{1}\right)\end{array}$ & $T$ & $P$ & Notability \\
\hline \multicolumn{5}{|l|}{ Linear } \\
\hline$x_{1}$ & 0.23 & 1.18 & 0.3023 & \\
\hline$x_{2}$ & 0.16 & 0.50 & 0.4970 & \\
\hline$x_{3}$ & -0.64 & 9.15 & 0.0128 & ** \\
\hline$X_{4}$ & 0.24 & 1.15 & 0.3088 & \\
\hline \multicolumn{5}{|l|}{ Quadratic } \\
\hline$x_{11}$ & -1.92 & 13.10 & 0.0047 & $* * *$ \\
\hline$x_{22}$ & 1.17 & 4.75 & 0.0544 & \\
\hline$x_{33}$ & -0.56 & 1.31 & 0.2790 & \\
\hline$X_{44}$ & $-2.386 \mathrm{E}-003$ & $3.722 \mathrm{E}-005$ & 0.9953 & \\
\hline \multicolumn{5}{|l|}{ Interaction } \\
\hline$x_{12}$ & -0.91 & 14.95 & 0.0031 & $* * *$ \\
\hline$x_{13}$ & -0.23 & 0.87 & 0.3725 & \\
\hline$X_{14}$ & -0.53 & 5.20 & 0.0457 & $* *$ \\
\hline$x_{23}$ & -0.072 & 0.095 & 0.7642 & \\
\hline$x_{24}$ & 0.33 & 1.89 & 0.1988 & \\
\hline$x_{34}$ & 0.54 & 5.14 & 0.0468 & ** \\
\hline$R^{2}$ & 0.81 & & & \\
\hline
\end{tabular}

Notes: $X_{1}=$ OA/MEOA ratio; $X_{2}=$ PTSA/MEOA ratio; $X_{3}=$ reaction temperature; $X_{4}=$ reaction time. ${ }^{* *} \mathrm{P}<0.05 ;{ }^{* * *} P<0.01$. T: $F$ test value See Table 1 for a description of the abbreviations. 
great reduction $0.05 \%$, which was predicted at $\mathrm{OA} /$ MEOA ratio of 0.2:1 ( $\mathrm{mol} / \mathrm{mol})$, PTSA/MEOA ratio of $0.4: 1(\mathrm{~mol} / \mathrm{mol})$ and reaction time at $4.5 \mathrm{~h}$. This abrupt reduction on $\mathrm{OOC} \%$ by high temperature $\left(110^{\circ} \mathrm{C}\right)$ shows a high increment on yield, $84.61 \%$, conversion, $83.54 \%$ and iodine value, $134.8 \mathrm{mg} / \mathrm{g}$, compared with the initial iodine value $\left(\mathrm{IV}^{\circ}\right) 77.65 \mathrm{mg} / \mathrm{g}$. In light of these changes, other optimization experiments were discontinued.

As described in the mechanism, most of the oxirane ring groups are opened, and, consequently, were converted into ester bonds in the molecule with hydroxyl group. At lower temperatures, a fairly low oxirane ring reduction (3.80\%) was observed at $90^{\circ} \mathrm{C}$ for $4.5 \mathrm{~h}$ of reaction compared with $0.05 \%$ at $110^{\circ} \mathrm{C}$ for $4.5 \mathrm{~h}$. At $100^{\circ} \mathrm{C}$, the $\mathrm{OOC} \%$ shows a smooth reduction during the reaction Table 1.

The quadratic regression coefficients obtained by employing the least squares method to predict quadratic polynomial models for the OOC\% of HYOOA $\left(Y_{1}\right)$, yield\% $\left(Y_{2}\right)$ and IV $\mathrm{mg} / \mathrm{g}\left(Y_{3}\right)$ are given in Tables 2, 3 and 4. The OOC\% response of HYOOA $\left(Y_{1}\right)$ shows that the linear term of reaction temperature $\left(X_{3}\right)$ was significant $(P<0.05)$ and highly significant $(P<0.01)$ for the IV $\mathrm{mg} / \mathrm{g}\left(Y_{3}\right)$. The quadratic term of OA/MEOA ratio $\left(X_{11}\right)$ was highly significant $(P<0.01)$ for both OOC\% $\left(Y_{1}\right)$ and IV $\mathrm{mg} / \mathrm{g}$

Table 3 Regression coefficients of the predicted quadratic polynomial model for the response variables of the yield\% of HYOOA

\begin{tabular}{|c|c|c|c|c|}
\hline Variables & $\begin{array}{c}\text { Coefficients }(ß), \\
\text { yield\% }\left(Y_{2}\right)\end{array}$ & $T$ & $P$ & Notability \\
\hline \multicolumn{5}{|l|}{ Linear } \\
\hline$\overline{x_{1}}$ & -11.76 & 18.38 & 0.0016 & $* * *$ \\
\hline$x_{2}$ & -6.39 & 4.75 & 0.0542 & \\
\hline$x_{3}$ & 1.11 & 0.17 & 0.6915 & \\
\hline$x_{4}$ & -2.57 & 0.81 & 0.3879 & \\
\hline \multicolumn{5}{|l|}{ Quadratic } \\
\hline$x_{11}$ & 6.50 & 0.91 & 0.3636 & \\
\hline$x_{22}$ & -5.68 & 0.67 & 0.4321 & \\
\hline$x_{33}$ & -4.02 & 0.41 & 0.5349 & \\
\hline$x_{44}$ & -8.11 & 2.58 & 0.1390 & \\
\hline \multicolumn{5}{|l|}{ Interaction } \\
\hline$x_{12}$ & -0.068 & $5.008 \mathrm{E}-004$ & 0.9826 & \\
\hline$x_{13}$ & -1.67 & & 0.6037 & \\
\hline$x_{14}$ & -0.81 & 0.29 & 0.7922 & \\
\hline$x_{23}$ & 2.97 & 0.073 & 0.3469 & \\
\hline$x_{24}$ & -0.64 & 0.97 & 0.8401 & \\
\hline$x_{34}$ & -1.81 & 0.043 & 0.5709 & \\
\hline$R^{2}$ & 0.81 & 0.34 & & \\
\hline
\end{tabular}

Abbreviations: Notes: $X_{1}$ OA/MEOA ratio, $X_{2}$ PTSA/MEOA ratio, $X_{3}$ reaction temperature, $X_{4}$ reaction time. ${ }^{* * *} P<0.01$. T: $F$ test value. See Table 1 for a description of the abbreviations.
Table 4 Regression coefficients of the predicted quadratic polynomial model for the response variables of the IV $\mathrm{mg} / \mathrm{g}$ of HYOOA

\begin{tabular}{|c|c|c|c|c|}
\hline Variables & $\begin{array}{c}\text { Coefficients }(ß), \\
\text { IV mg/g }\left(Y_{3}\right)\end{array}$ & $T$ & $P$ & Notability \\
\hline \multicolumn{5}{|l|}{ Linear } \\
\hline$X_{1}$ & -2.79 & 1.54 & 0.2432 & \\
\hline$X_{2}$ & -2.02 & 0.71 & 0.4205 & \\
\hline$x_{3}$ & 7.84 & 12.32 & 0.0056 & $* * *$ \\
\hline$x_{4}$ & -3.17 & 1.85 & 0.2034 & \\
\hline \multicolumn{5}{|l|}{ Quadratic } \\
\hline$x_{11}$ & 22.75 & 16.54 & 0.0023 & $* * *$ \\
\hline$x_{22}$ & -12.57 & 4.90 & 0.0513 & \\
\hline$x_{33}$ & 6.80 & 1.76 & 0.2144 & \\
\hline$X_{44}$ & -0.30 & 5.153E-003 & 0.9442 & \\
\hline \multicolumn{5}{|l|}{ Interaction } \\
\hline$x_{12}$ & 10.60 & 18.35 & 0.0016 & $* * *$ \\
\hline$X_{13}$ & 1.76 & 0.47 & 0.5064 & \\
\hline$X_{14}$ & 5.52 & 5.06 & 0.0482 & $* *$ \\
\hline$x_{23}$ & -1.24 & 0.25 & 0.6247 & \\
\hline$x_{24}$ & -3.79 & 2.23 & 0.1663 & \\
\hline$x_{34}$ & -6.97 & 7.61 & 0.0202 & $* *$ \\
\hline$R^{2}$ & 0.84 & & & \\
\hline
\end{tabular}

Notes: $X_{1}=\mathrm{OA} / \mathrm{MEOA}$ ratio; $X_{2}=\mathrm{PTSA} / \mathrm{MEOA}$ ratio; $X_{3}=$ reaction temperature; $X_{4}=$ reaction time. ${ }^{* *} P<0.05 ;{ }^{* * *} P<0.01 . T$ : $F$ test value. See Table 1 for a description of the abbreviations.

Table 5 Analysis of variance (ANOVA) for all the responses of HYOOA

\begin{tabular}{|c|c|c|c|c|c|c|c|}
\hline & Source & $D f$ & $\begin{array}{l}\text { Sum of } \\
\text { squares }\end{array}$ & $\begin{array}{l}\text { Mean } \\
\text { square }\end{array}$ & $F$ value & Prob $>F$ & \\
\hline & Model & 14 & 30.35 & 2.17 & 3.19 & 0.0357 & Significant \\
\hline \multirow[t]{4}{*}{$Y_{1}$} & Residual & 10 & 6.80 & 0.68 & & & \\
\hline & Lack-of-fit & 5 & 2.67 & 0.53 & 0.65 & 0.6783 & $\begin{array}{l}\text { Not } \\
\text { significant }\end{array}$ \\
\hline & Pure error & 5 & 4.13 & 0.83 & & & \\
\hline & Model & 14 & 4862.62 & 347.33 & 3.07 & 0.0402 & Significant \\
\hline \multirow[t]{4}{*}{$Y_{2}$} & Residual & 10 & 1130.50 & 113.05 & & & \\
\hline & Lack-of-fit & 5 & 437.76 & 87.55 & 0.63 & 0.6866 & $\begin{array}{l}\text { Not } \\
\text { significant }\end{array}$ \\
\hline & Pure error & 5 & 692.74 & 138.55 & & & \\
\hline & Model & 14 & 4283.91 & 305.99 & 4.03 & 0.0161 & Significant \\
\hline \multirow[t]{3}{*}{$Y_{3}$} & Residual & 10 & 758.84 & 75.88 & & & \\
\hline & Lack-of-fit & 5 & 347.14 & 69.43 & 0.84 & 0.5719 & $\begin{array}{l}\text { Not } \\
\text { significant }\end{array}$ \\
\hline & Pure error & 5 & 411.69 & 82.34 & & & \\
\hline
\end{tabular}



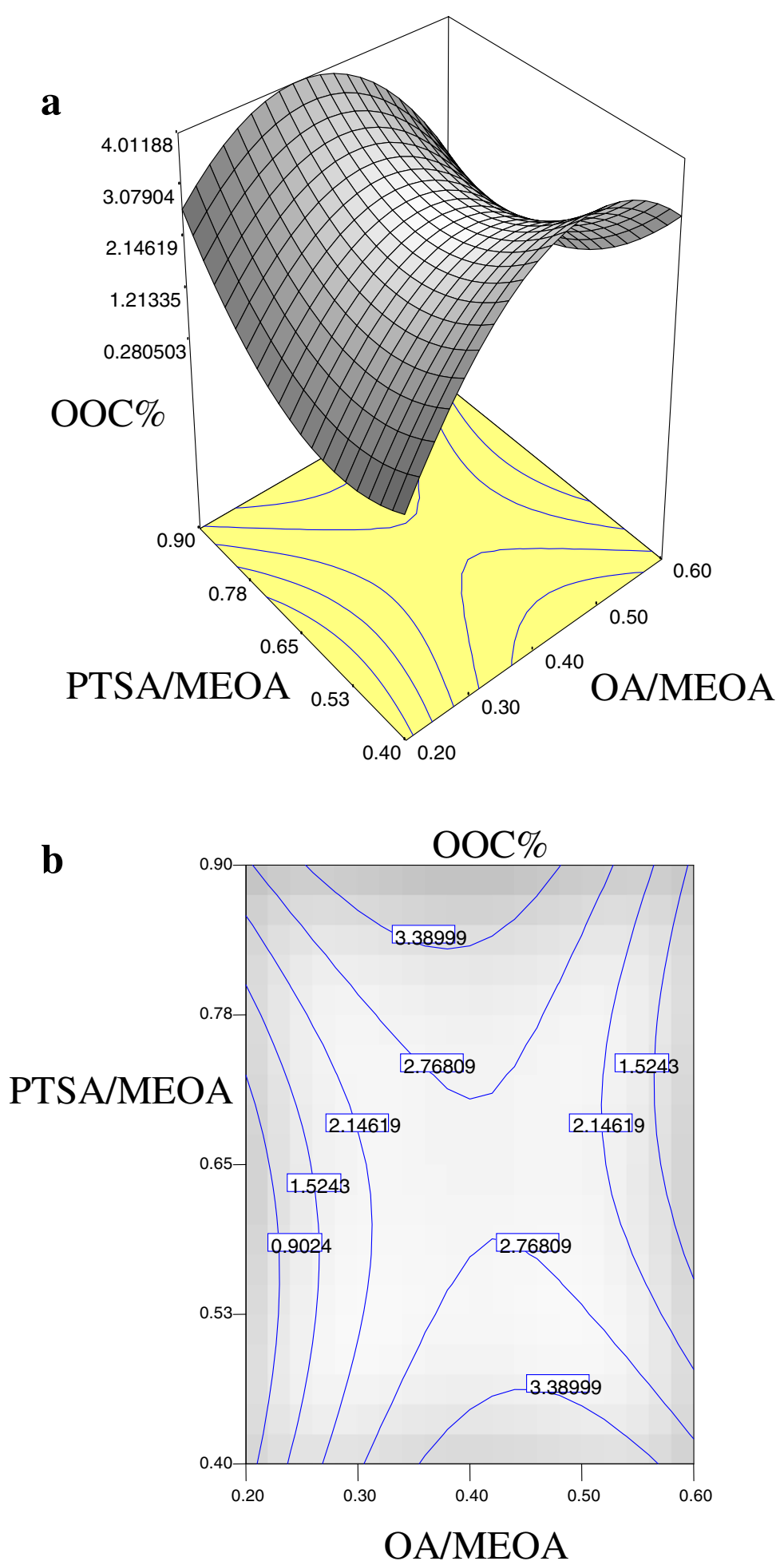

Figure 2 Response surface (a) and contour plots (b) for the OOC\%. Response surface (a) and contour plots (b) for the OA/MEOA ratio $(\mathrm{X} 1, \mathrm{~mol} / \mathrm{mol})$ and PTSA/MEOA ratio $(\mathrm{X} 2, \mathrm{~mol} / \mathrm{mol})$ on the OOC\%.

$\left(Y_{3}\right)$. The interaction terms of $\left(X_{12}\right)$ were highly significant $(P<0.01)$ for both OOC\% $\left(Y_{1}\right)$ and IV $\mathrm{mg} / \mathrm{g}\left(Y_{3}\right)$, while the interaction terms of $\left(X_{14}\right)$ and $\left(X_{34}\right)$ were significant
$(P<0.05)$ for both OOC\% $\left(Y_{1}\right)$ and IV $\mathrm{mg} / \mathrm{g}\left(Y_{3}\right)$. Highly significant $(P<0.01)$ terms of yield\% $\left(Y_{2}\right)$ for the OA/MEOA $\left(X_{1}\right)$ were linear. 

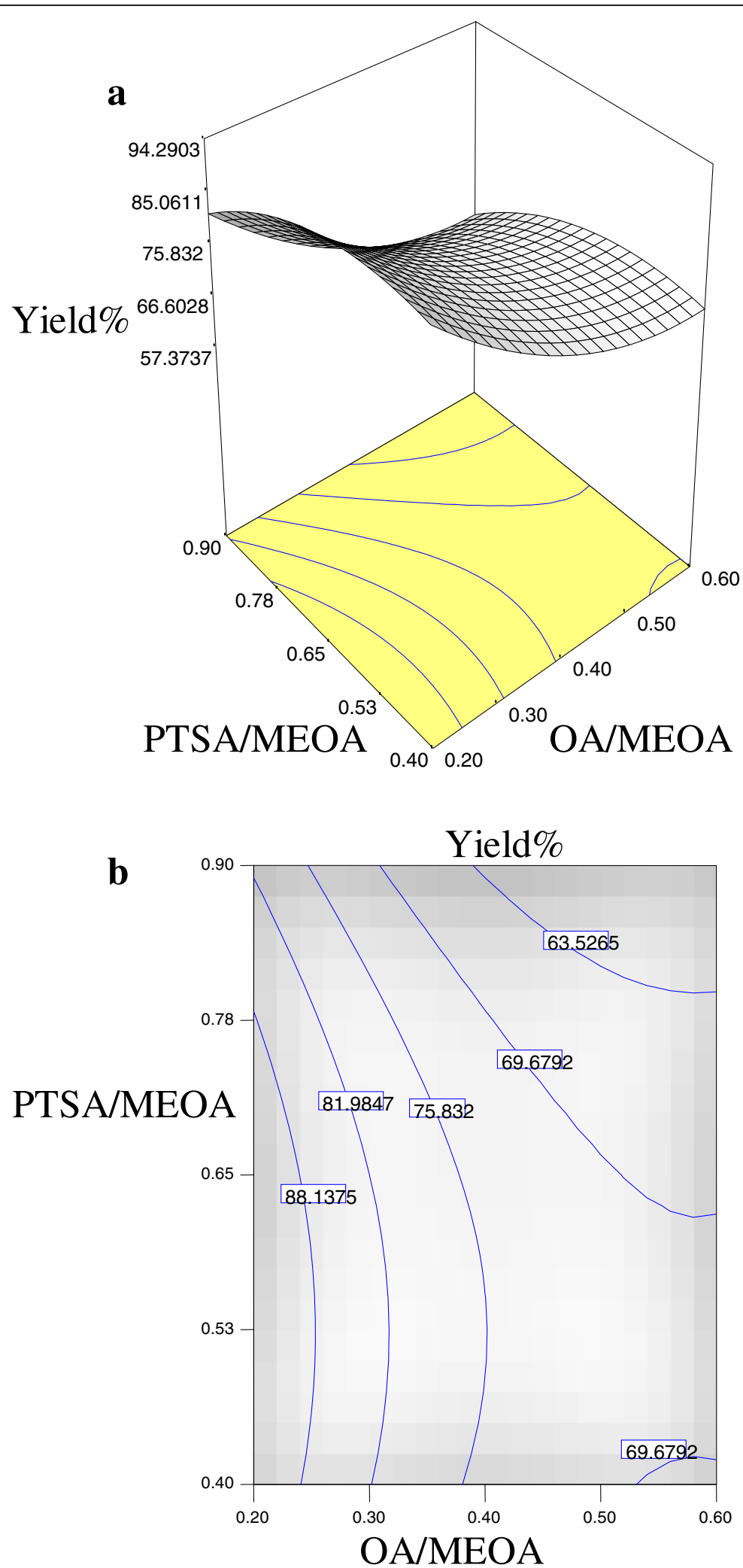

Figure 3 Response surface (a) and contour plots (b) for the yield\%. Response surface (a) and contour plots (b) for the OA/MEOA ratio (X1, $\mathrm{mol} / \mathrm{mol})$ and PTSA/MEOA ratio $(\mathrm{X} 2, \mathrm{~mol} / \mathrm{mol})$ on the yield\%. 

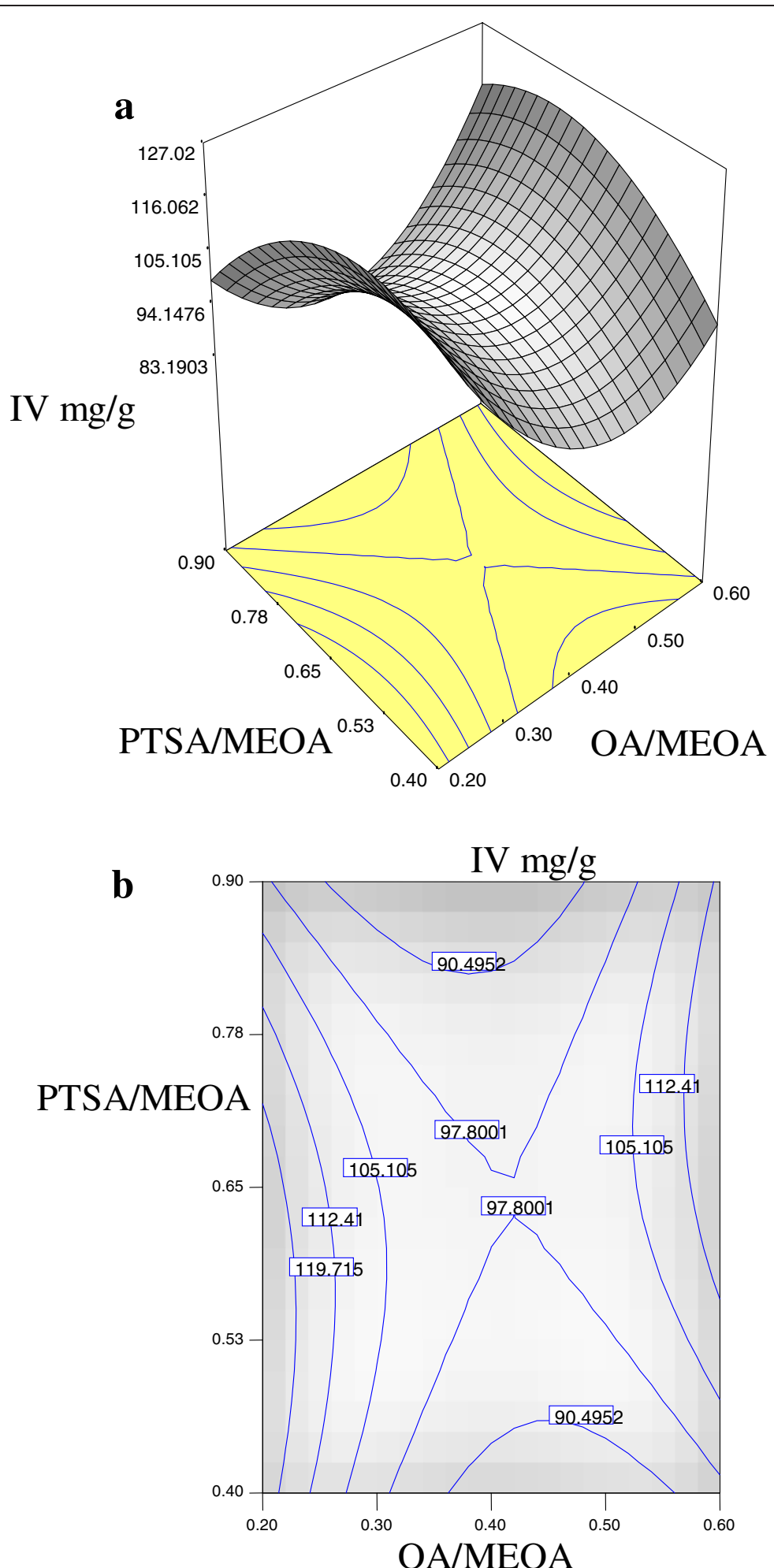

Figure 4 Response surface (a) and contour plots (b) for the IV $\mathbf{m g} / \mathbf{g}$. Response surface (a) and contour plots (b) for the OA/MEOA ratio $(\mathrm{X} 1, \mathrm{~mol} / \mathrm{mol})$ and PTSA/MEOA ratio $(\mathrm{X} 2, \mathrm{~mol} / \mathrm{mol})$ on the $\mathrm{IV} \mathrm{mg} / \mathrm{g}$. 
From the experimental results in Table 1 and Equations $(1,2,3)$ a second order polynomial equation was developed (in coded units) that could relate the OOC\% $\left(Y_{1}\right)$, yield\% $\left(Y_{2}\right)$ and IV $\mathrm{mg} / \mathrm{g}\left(Y_{3}\right)$ of HYOOA to the parameters under study. The following quadratic model is explained in Equations (1,2 and 3).

$$
\begin{aligned}
Y_{1}= & +2.84+0.23 X_{1}+0.16 X_{2}-0.64 X_{3}+0.24 X_{4}-1.92 X_{1}{ }^{2} \\
& +1.17 X_{2}{ }^{2}-0.56 X_{3}{ }^{2}-2.386 \mathrm{E}-003 X_{4}{ }^{2}-0.91 X_{1} X_{2} \\
& -0.23 X_{1} X_{3}-0.53 X_{1} X_{4}-0.072 X_{2} X_{3}+0.33 X_{2} X_{4} \\
& +0.54 X_{3} X_{4}
\end{aligned}
$$

$$
\begin{aligned}
Y_{2}= & +74.11-11.76 X_{1}-6.39 X_{2}+1.11 X_{3}-2.57 X_{4} \\
& +6.50 X_{1}^{2}-5.68 X_{2}^{2}-4.02 X_{3}^{2}-8.11 X_{4}^{2}-0.068 X_{1} X_{2} \\
& -1.67 X_{1} X_{3}-0.81 X_{1} X_{4}+2.97 X_{2} X_{3}-0.64 X_{2} X_{4} \\
& -1.81 X_{3} X_{4}
\end{aligned}
$$

$$
\begin{aligned}
Y_{3}= & +96.11-2.79 X_{1}-2.02 X_{2}+7.84 X_{3}-3.17 X_{4} \\
& +22.75 X_{1}^{2}-12.57 X_{2}^{2}+6.80 X_{3}^{2}-0.30 X_{4}{ }^{2} \\
& +10.60 X_{1} X_{2}+1.76 X_{1} X_{3}+5.52 X_{1} X_{4}-1.24 X_{2} X_{3} \\
& -3.79 X_{2} X_{4}-6.97 X_{3} X_{4}
\end{aligned}
$$

The lack of fit $F$-value for the all responses $Y_{1}, Y_{2}$ and $Y_{3}$ shows that the lack of fit is not significant $(P>0.05)$ relative to the pure error. This indicates that all the models predicted for the responses were adequate. The regression models for the data on responses $Y_{1}, Y_{2}$ and $Y_{3}$ were significant $(P<0.05)$ with satisfactory $R^{2}$. However, the $R^{2}$ for the $Y_{1}, Y_{2}$ and $Y_{3}$ were $(0.81,0.81$ and 0.84 , respectively), although the model was significant. Table 5 summarizes the analysis of variance (ANOVA) of all the responses $Y_{1}, Y_{2}$ and $Y_{3}$ of this study.

The significant interaction variables in the fitted models (Tables 2, 3 and 4) were chosen as the axes (OA/MEOA ratio; $X_{1}$, PTSA/MEOA ratio; $X_{2}$, reaction temperature; $X_{3}$ and reaction time; $X_{4}$ ) for the response surface

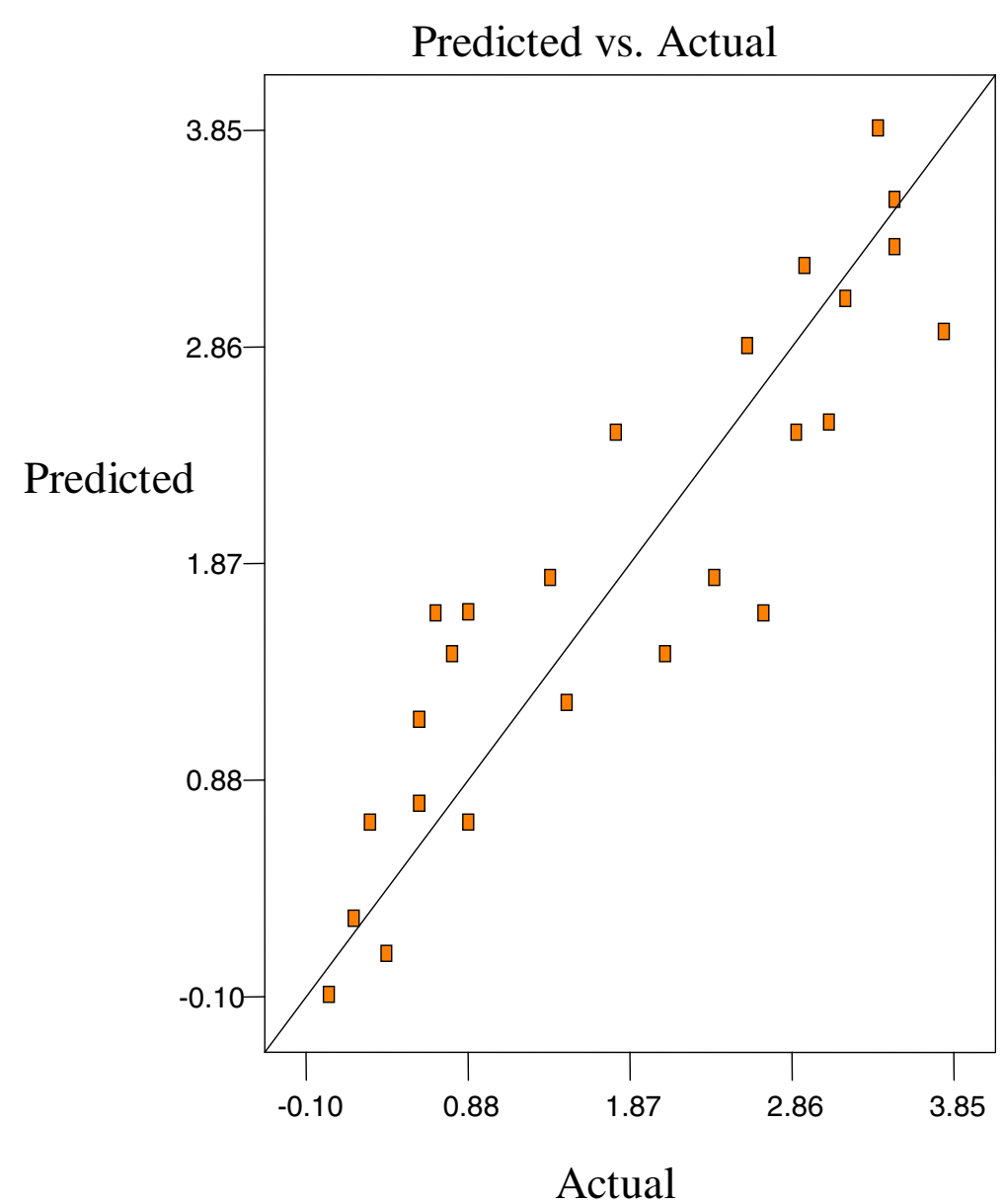

Figure 5 Predicated vs. actual plot of $\mathrm{Y} 1$. 
plots. The relationships between independent and dependent variables are shown in the three-dimensional representation as response surfaces. In a contour plot, the curves of equal response values are drawn on a plane whose coordinates represent the levels of the independent factors. Each contour represents a specific value for the height of the surface above the plane defined for combination of the levels of the factors. Therefore, different surface height values enable one to focus attention on the levels of the factors at which changes in the surface height occur (Hwang \& Erhan 2001).

Figures 2, 3 and 4 are the Design-Expert plots for all the responses. In the oxirane ring opening reaction for HYOOA, performing the technique using high reaction temperature would give the desired OOC\% of HYOOA. The relationships between the parameters and oxirane ring opening of HYOOA were linear or almost linear. Reconfirmation of the optimal condition experiment was repeated three times. The observed value was reasonably close to the predicted value, as shown in Figures 5, 6 and 7.
The lowest OOC of $0.05 \%$ could be obtained by using a low ratio of OA/MEOA and low ratio of PTSA/MEOA at high reaction temperature, such as other studies, which have used a lower PTSA ratio (Salimon et al. 2012a). Experimental variables should be carefully controlled in order to reduce the OOC\% of interest with reasonable yield\%. Optimum conditions of the experiment to obtain high yield\% of HYOOA and lowest OOC $\%$ were predicted at a ratio of OA/MEOA of 0.2:1 $(\mathrm{mol} / \mathrm{mol})$, ratio of PTSA/MEOA of $0.4: 1(\mathrm{~mol} / \mathrm{mol})$, reaction temperature $110^{\circ} \mathrm{C}$, and $4.5 \mathrm{~h}$ reaction time. In this condition, the OOC of HYOOA was $0.05 \%$, yield was $84.61 \%$, and IV was $134.8 \mathrm{mg} / \mathrm{g}$ (Table 1 ).

\section{FTIR analysis of HYOOA}

The spectrum from the FTIR analysis displays several absorption peaks, as shown in Figure 8. The main peaks and their assignment to functional groups are given in Table 6. The FTIR peaks of HYOOA indicate the disappearance of the absorption band at $820 \mathrm{~cm}^{-1}$, which

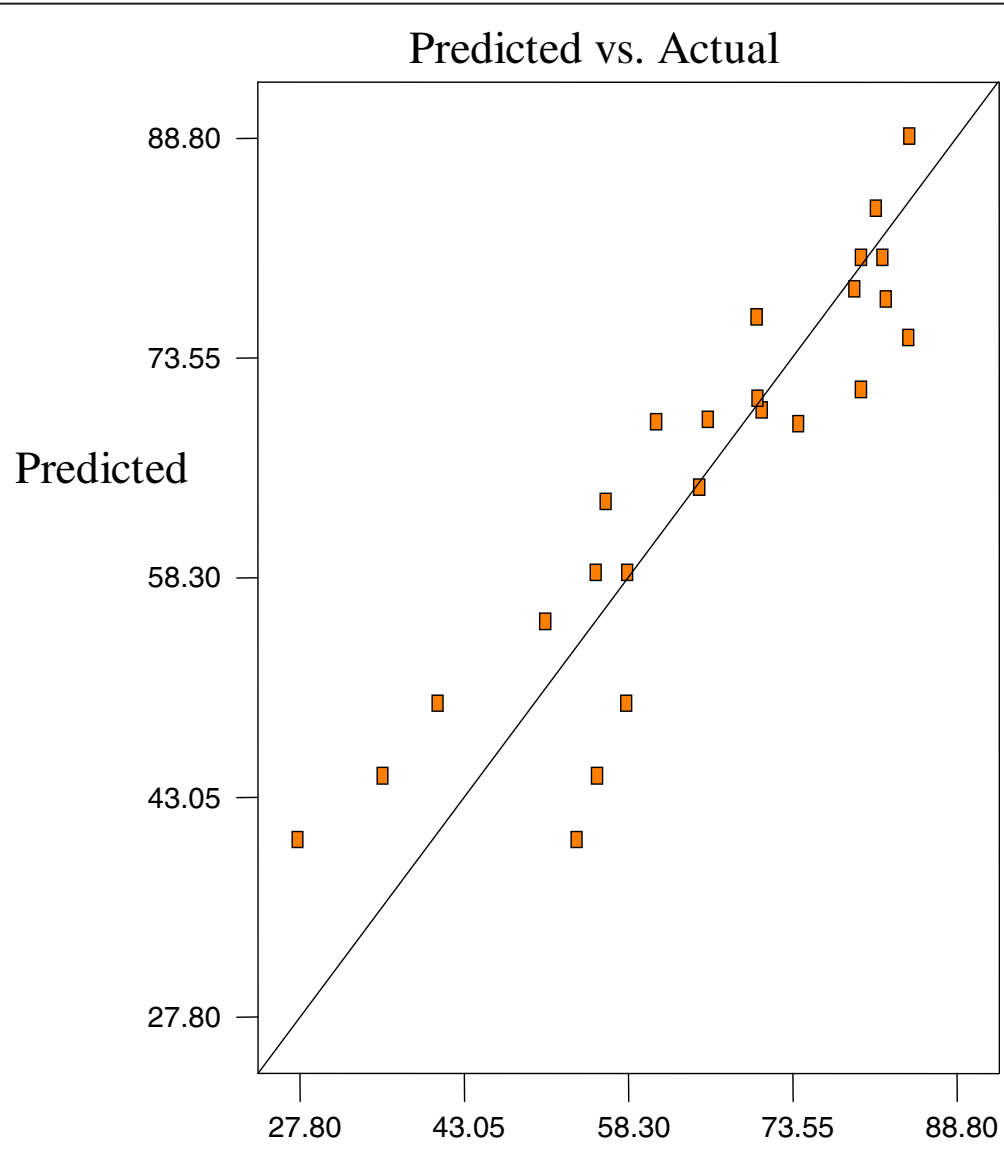

Actual

Figure 6 Predicated vs. actual plot of Y2. 


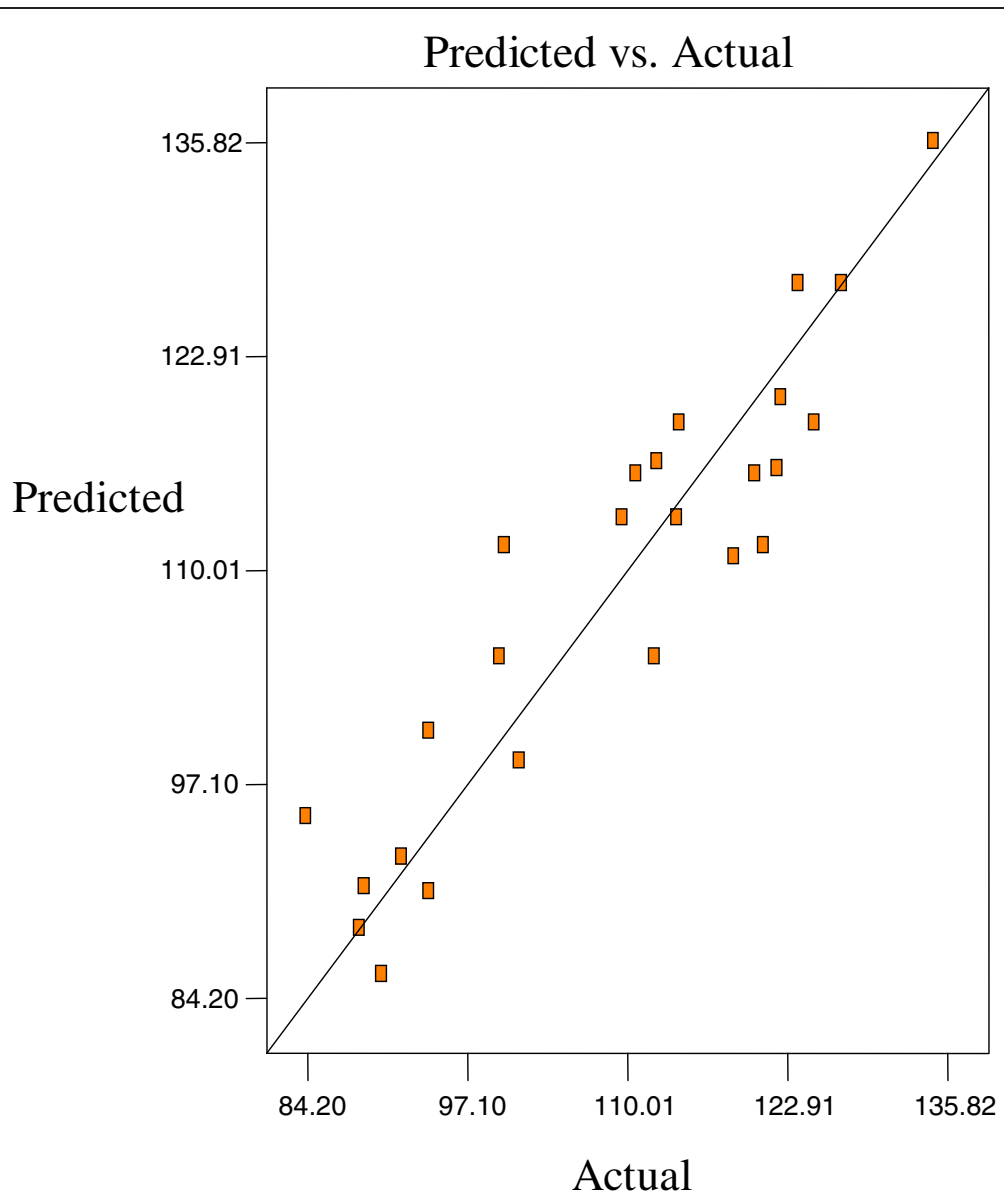

Figure 7 Predicated vs. actual plot of Y3.

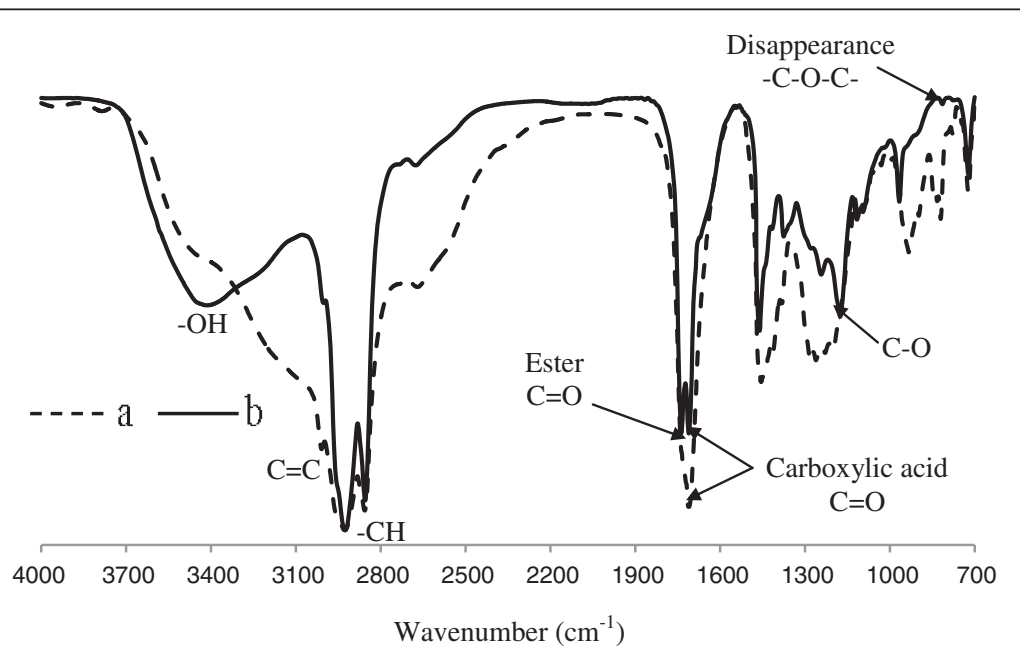

Figure 8 FTIR spectra of the MEOA (a) and HYOOA (b). 
Table 6 The main wavenumbers in the FTIR functional groups of MEOA and HYOOA

\begin{tabular}{|c|c|c|}
\hline $\begin{array}{c}\text { Wavenumber } \\
\text { of } \text { MEOA }^{\mathrm{a}}\end{array}$ & $\begin{array}{l}\text { Wavenumber } \\
\text { of }^{H_{Y O O O A}}{ }^{\mathrm{b}}\end{array}$ & Functional group \\
\hline- & 3413 & $\mathrm{OH}$ stretching (alcohol) \\
\hline- & 1737 & $\mathrm{C}=\mathrm{O}$ stretching vibration (ester) \\
\hline- & 1176,1117 & C-O bending vibration (ester) \\
\hline 820 & - & C-O-C oxirane ring \\
\hline
\end{tabular}

Notes: Monoepoxide linoleic acid (a); 9,12-hydroxy-10,13-oleioxy-12,9octadecanoic acid (b).

belongs to the oxirane ring. For the ester carbonyl functional groups $\mathrm{C}=\mathrm{O}$ of HYOOA at $1741 \mathrm{~cm}^{-1}$ and the carboxylic carbonyl vibration functional group at $1711 \mathrm{~cm}^{-1}$, which show the same absorption band in MEOA at $1711 \mathrm{~cm}^{-1}$. The FTIR peaks at 2925 to $2855 \mathrm{~cm}^{-1}$ indicate the $\mathrm{CH}_{2}$ and $\mathrm{CH}_{3}$ scissoring of MEOA and HYOOA.

The FTIR spectroscopy analysis of MEOA and HYOOA indicate the presence of a peak at $3003-3008 \mathrm{~cm}^{-1}$, which belongs to the double bond $\mathrm{C}=\mathrm{C}$ (stretching aliphatic), while at $3413 \mathrm{~cm}^{-1}$, it belongs to $\mathrm{OH}$ stretching of HYOOA. The peaks at 1176 and $1117 \mathrm{~cm}^{-1}$ of HYOOA are referred to as $(\mathrm{C}-\mathrm{O})$ stretching ester. FTIR spectrum also shows absorption bands at $723 \mathrm{~cm}^{-1}$ for $(\mathrm{C}-\mathrm{H})$ group vibration. A similar observation has been reported for the FTIR spectrum of oxirane ring opening of epoxide oleic acid (Salimon et al. 2012a).

\section{${ }^{1} \mathrm{H}$ And ${ }^{13} \mathrm{C}$ NMR analysis of HYOOA}

\section{a. ${ }^{1} \mathrm{H}$ NMR analysis}

${ }^{1} \mathrm{H}$ NMR spectroscopy shows the main signals assignments of MEOA and HYOOA, as shown in Table 7. The ${ }^{1} \mathrm{H}$ NMR spectra for the products HYOOA show the disappearance of the ring opening $(-\mathrm{CH}-\mathrm{O}-\mathrm{CH}-)$ in the range of 2.92-3.12 $\mathrm{ppm}$, which refers to the MEOA, Figure 9. The distinguishable peaks appear in HYOOA $\mathrm{CH}-\mathrm{OH}$ at $3.62 \mathrm{ppm}$ while $-\mathrm{CHOCOR}$ at $4.06 \mathrm{ppm}$, which did not appear in MEOA (Figure 9a and b).

The signals at $0.82-0.84 \mathrm{ppm}$ refer to the methylene group $\left(-\mathrm{CH}_{3}\right)$ of HYOOA, which also appears in MEOA

Table 7 The main signals present in ${ }^{1} \mathrm{H}$ NMR functional groups of MEOA and HYOOA

\begin{tabular}{ccc}
\hline $\boldsymbol{\delta}$ (ppm) of MEOA $^{\mathbf{a}}$ & $\boldsymbol{\delta}(\mathbf{p p m})$ of $\mathbf{H Y O O A}^{\mathbf{b}}$ & Assignment \\
\hline $0.86-0.88$ & $0.82-0.84$ & $-\mathrm{CH}_{3}$ \\
$1.29-2.03$ & $1.23-2.06$ & $-\mathrm{CH}_{2}$ \\
$2.29-2.33$ & $2.26-2.33$ & $-\mathrm{CH}$ \\
$2.92-3.12$ & - & $-\mathrm{CH}-\mathrm{O}-\mathrm{CH}-$ \\
- & 3.62 & $-\mathrm{CHOH}$ \\
- & 4.06 & $-\mathrm{CHOCOR}$ \\
$5.38-5.49$ & $5.31-5.40$ & $-\mathrm{CH}=\mathrm{CH}-$ \\
\hline
\end{tabular}

Notes: Mono-epoxide linoleic acid (a); 9,12-hydroxy-10,13-oleioxy-12,9octadecanoic acid (b). next to the terminal methyl $\left(-\mathrm{CH}_{2}\right)$ at $1.23-2.06 \mathrm{ppm}$ of HYOOA. The other distinctive signals were methine at about 2.26-2.33 ppm, which are common for these types of compounds (Doll et al. 2007). However, the methane proton signal $(-\mathrm{CH}=\mathrm{CH}-)$ was shifted upfield to about 5.31-5.40 ppm of HYOOA.

\section{b. ${ }^{13} \mathrm{C}$ NMR analysis}

Figures $10 \mathrm{a}$ and $\mathrm{b}$ indicate the ${ }^{13} \mathrm{C}$ NMR spectrum of MEOA and HYOOA, respectively. The ${ }^{13} \mathrm{C}$ spectroscopy shows the main signals assignment of MEOA and HYOOA, as shown in Table 8. The signals at 179.32 and $178.11 \mathrm{ppm}$ refer to the carbon atom of the carbonyl group (carboxylic acid) for MEOA and HYOOA, respectively, while $174.1 \mathrm{ppm}$ appear in HYOOA, which refers to the ester group. The signals at 127.90 to $130.57 \mathrm{ppm}$ refer to the unsaturated carbon atoms (olefin carbons) for both MEOA and HYOOA.

Figure 10b confirms the disappearance of the oxirane ring, which appeared in MEOA at 54.59-57.29 ppm and the appearance $\mathrm{OH}$ alcohol in HYOOA at about $64.41 \mathrm{ppm}$. The other distinctive signals were aliphatic carbons HYOOA at about 25.76-34.38 ppm, which are common for these types of compounds, and belong to the methylene carbon atoms of MEOA and HYOOA (Salimon et al. 2012a).

\section{Methodology Experimental procedure}

The oxirane ring opening reaction was carried out using oleic acid (OA) and p-toluene sulfonic acid (PTSA) as catalyst to prepare 9,12-hydroxy-10,13-oleioxy-12-octadecanoic acid (HYOOA) (Salimon et al. 2012a). Table 9 shows the different OA/MEOA ratios, different PTSA/ MEOA ratios, different reaction temperatures and different reaction times using D-Optimal design. Factors such as ratio OA/MEOA $\left(\mathrm{mol} / \mathrm{mol}, \mathrm{X}_{1}\right), \mathrm{PTSA} / \mathrm{MEOA}$ $\left(\mathrm{mol} / \mathrm{mol}, \mathrm{X}_{2}\right)$, reaction temperature $\left({ }^{\circ} \mathrm{C}, \mathrm{X}_{3}\right)$ and reaction time $\left(\mathrm{h}, \mathrm{X}_{4}\right)$ were performed under the same experimental conditions. MEOA (1.55 g; $0.005 \mathrm{~mol}$ ) and ratio PTSA/MEOA (0.2:1-0.6:1 $\mathrm{mol} / \mathrm{mol})$ were dissolved in toluene $(10 \mathrm{~mL})$ in a $250-\mathrm{mL}$ three-neck flask equipped with a cooler, dropping funnel and thermometer. The mixture was kept at $50^{\circ} \mathrm{C}$. OA/MEOA ratio $(0.4: 1$ 0.9:1 $\mathrm{mol} / \mathrm{mol}$ ) was added during $1.5 \mathrm{~h}$ in order to keep the reaction mixture temperature under $70-80^{\circ} \mathrm{C}$. The reaction mixture was subsequently heated to different temperatures $90-110^{\circ} \mathrm{C}$, and refluxed at different times 3-6 $\mathrm{h}$, at this temperature range. After reaction termination, the heating was stopped and the mixture was left to stand overnight at ambient temperature. The mixture was washed with the water and the organic layer was dried over anhydrous sodium sulphate and the solvent was removed using the vacuum evaporator. The oxirane 


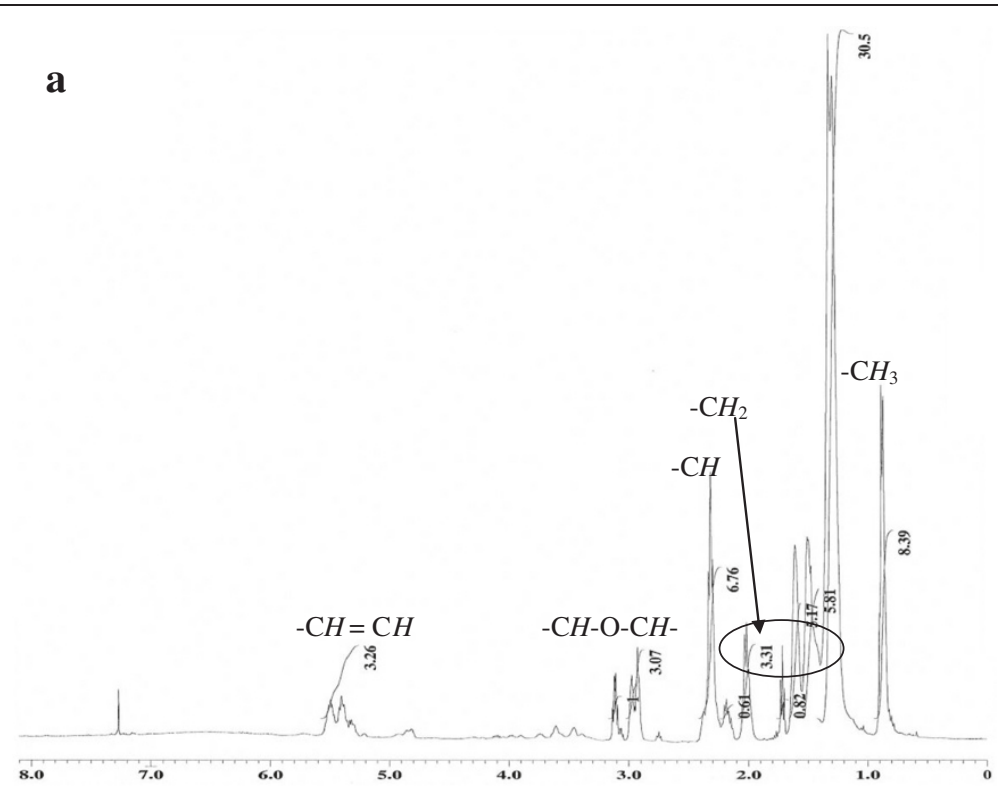

\section{b}

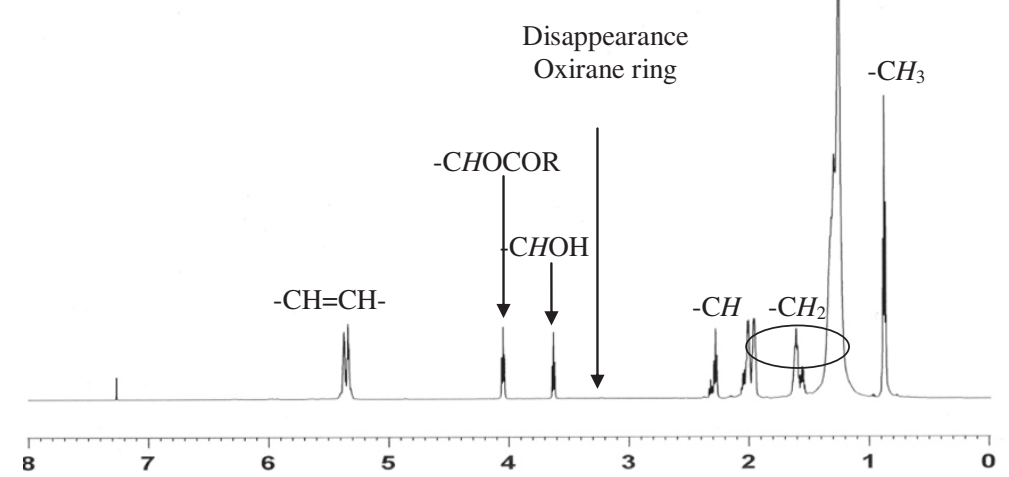

Figure 9 1H NMR spectrum of MEOA (a) and HYOOA (b).

ring content (OOC\%), yield\% and iodine value (IV $\mathrm{mg} / \mathrm{g}$ ) were measured. The FTIR, ${ }^{1} \mathrm{H},{ }^{13} \mathrm{C}$ were analyzed.

\section{Experimental design and statistical analysis}

To explore the effect of the operation variables on the response in the region of investigation, a $\mathrm{D}$ optimal design was performed. Ratio of OA/MEOA $\left(\mathrm{mol} / \mathrm{mol}, X_{1}\right)$, ratio of PTSA/MEOA $\left(\mathrm{mol} / \mathrm{mol}, X_{2}\right)$, reaction temperature $\left({ }^{\circ} \mathrm{C}, X_{3}\right)$, and reaction time $\left(\mathrm{h}, X_{4}\right)$ were selected as independent variables. The range of values and coded levels of the variables are given in Table 9. Each variable to be optimized was coded at three levels: $-1,0$, and +1 . A quadratic polynomial regression model was assumed for predicting individual
Y variables. The model proposed for each response of Y was:

$$
\mathrm{Y}=\beta_{0}+\sum \beta_{\mathrm{i}} \mathrm{x}_{\mathrm{i}}+\sum \beta_{\mathrm{ii}} \mathrm{x}_{\mathrm{i}}^{2}+\sum \sum \beta_{\mathrm{ij}} \mathrm{x}_{\mathrm{i}} \mathrm{x}_{\mathrm{j}}
$$

Where $\beta_{0} ; \beta_{\mathrm{i}} ; \beta_{\mathrm{ii}}$ and $\beta_{\mathrm{ij}}$ are constant, linear, square and interaction regression coefficient terms, respectively, and $x_{i}$ and $x_{j}$ are independent variables. The Minitab software version 14 (Minitab Inc., USA) was used for multiple regression analysis, analysis of variance (ANOVA), and analysis of ridge maximum of data in the response surface regression (RSREG) procedure. The goodness of fit of the model was evaluated by the coefficient of determination $R^{2}$ and the analysis of variance (ANOVA). Response surfaces 


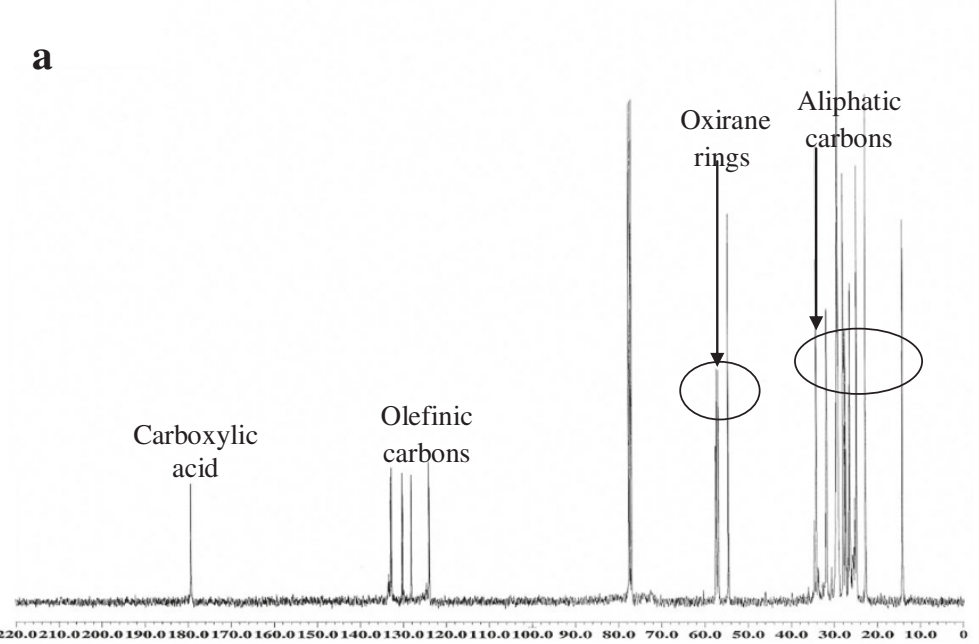

b

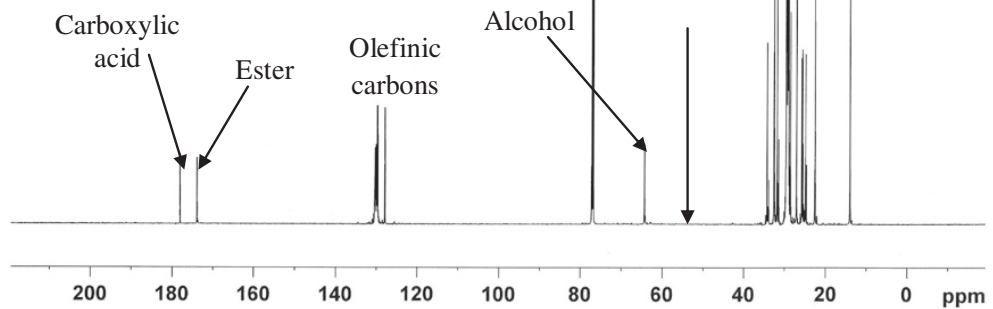

Figure 10 13C NMR spectrum of MEOA (a) and HYOOA (b).

Table 8 The main signals present in ${ }^{13} \mathrm{C}$ NMR functional groups of MEOA and HYOOA

\begin{tabular}{ccc}
\hline $\boldsymbol{\delta}$ (ppm) of MEOA $^{\mathbf{a}}$ & $\boldsymbol{\delta}$ (ppm) of HYOOA $^{\mathbf{b}}$ & Assignment \\
\hline $22.69-34.15$ & $25.76-34.38$ & Aliphatic carbons \\
$54.59-57.29$ & - & ( \\
- & 64.41 & Epoxide groups \\
$124.02-132.89$ & $127.90-130.57$ & $-\mathrm{CH}=\mathrm{CH}$ - Olefinic carbons \\
- & 174.01 & $\mathrm{C}=$ O Ester \\
179.32 & 178.11 & $\mathrm{C}=$ O Carboxylic acid \\
\hline
\end{tabular}

Notes: Mono-epoxide linoleic acid (a); 9,12-hydroxy-10,13-oleioxy-12,9octadecanoic acid (b). and contour plots were developed using the fitted quadratic polynomial equations obtained from RSREG analysis and holding the independent variables with the least effect on the response at two constant values and changing the levels of the other two variables (Salimon et al. 2012b).

Table 9 Independent variables and their levels for D-optimal design of the oxirane ring opening reaction

\begin{tabular}{lcccc}
\hline Independent variables & & \multicolumn{3}{c}{ Variable levels } \\
\cline { 3 - 5 } & & $\mathbf{- 1}$ & $\mathbf{0}$ & $\mathbf{+ 1}$ \\
\hline 1. OA/MEOA $(\mathrm{mol} / \mathrm{mol})$ & $X_{1}$ & 0.2 & 0.4 & 0.6 \\
2. PTSA/MEOA $(\mathrm{mol} / \mathrm{mol})$ & $X_{2}$ & 0.4 & 0.65 & 0.9 \\
3. Temperature $\left({ }^{\circ} \mathrm{C}\right)$ & $X_{3}$ & 90 & 100 & 110 \\
4. Time $(\mathrm{h})$ & $X_{4}$ & 3 & 4.5 & 6 \\
\hline
\end{tabular}




\section{Conclusion}

In this work described the process of a systematic approach to chemically modify the MEOA to yield monoester (HYOOA) biolubricant capable of operating at low temperatures. The optimum conditions for the experiment using D-optimal design to obtain high yield\% of 84.61, conversion\% of 83.54 and lowest OOC\% of 0.05 were predicted at OA/MEOA ratio of $0.2: 1(\mathrm{~mol} / \mathrm{mol})$, PTSA/MEOA ratio of $0.4: 1(\mathrm{~mol} / \mathrm{mol})$, reaction temperature at $110^{\circ} \mathrm{C}$, and reaction time at $4.5 \mathrm{~h}$.

\section{Competing interests}

The authors declare that they have no competing interests.

\section{Authors' contributions}

JS \& BMA developed the concept analyzed the data and drafted the manuscript. RMY, NS \& EY provided advice on the testing methods. EY performed the characterization methods. All of the authors read and approved the final manuscript.

\section{Acknowledgements}

The authors thank the Universiti Kebangsaan Malaysia for funding ("Code AP-2011-17", "DPP-2013-054" and "UKM-MI-OUP-2011") and (Code AP-2012-017, DLP-2013-002).

Received: 23 July 2013 Accepted: 20 August 2013

Published: 2 September 2013

\section{References}

Campanella A, Baltanás MA (2005) Degradation of the oxirane ring of epoxidized vegetable oil in liquid-liquid systems: II. Reactivity with solvated acetic acid and peracetic acids. Lat Am Appl Res 35:211-216

Doll KM, Sharma BK, Erhan SZ (2007) Synthesis of branched methyl hdroxy stearates including an ester from bio-based levulinic acid. Ind Eng Chem Res 46:3513-3519

Hwang H, Erhan SZ (2001) Modification of epoxidized soybean oil for lubricant formulations with improved oxidative stability and low pour point. J Am Oil Chem Soc 78:1179-1184

Lathi PS, Mattiasson B (2007) Green approach for the preparation of biodegradable lubricant base stock from epoxidized vegetable oil. Appl Catal Environ 69:207-212

Lozada Z, Suppes GJ, Tu Y-C, Hsieh F-H (2009) Soy-based polyols from oxirane ring opening by alcoholysis reaction. J Appl Polym Sci 113:2552-2560

Moser BR, Sharma BK, Doll KM, Erhan SZ (2007) Diesters from oleic acid: synthesis, low temperature properties, and oxidative stability. J Am Oil Chem Soc 84:675-680

Özgülsün A, Karasmanoğlu F (1999) Environmentally friendly lubricating oil candidate. Appl Biochem Biotechnol 77:38-89

Salimon J, Salih N, Abdullah BM (2012a) Production of chemoenzymatic catalyzed monoepoxide biolubricant: optimization and physicochemical characteristics. J Biomed Biotechnol 693848:11

Salimon J, Abdullah BM, Salih N (2012b) Selectively increasing of polyunsaturated (18:2) and monounsaturated (18:1) fatty acids in Jatropha curcas seed oil by crystallization using D-optimal design. Chem Cent J 6:65

Schuster H, Rios LA, Weckes PP, Hoelderich WF (2008) Heterogeneous catalysts for the production of new lubricants with unique properties. Appl Catal Gen 348:266-270

Wu M, Ding H, Wang S, Xu S (2008) Optimization conditions for the purification of linoleic acid from sunflower oil by urea complex fractionation. J Am Oil Chem Soc 85:677-684

\section{doi:10.1186/2193-1801-2-429}

Cite this article as: Salimon et al:: Synthesis and optimization ring opening of monoepoxide linoleic acid using $p$-toluenesulfonic acid. SpringerPlus 2013 2:429.

\section{Submit your manuscript to a SpringerOpen ${ }^{\circ}$ journal and benefit from:}

- Convenient online submission

- Rigorous peer review

- Immediate publication on acceptance

- Open access: articles freely available online

- High visibility within the field

- Retaining the copyright to your article

Submit your next manuscript at $>$ springeropen.com 